\title{
Skills Lecturers Possess for Quality Delivery of the Clothing and Textiles Curriculum
}

\author{
Verity Muzenda \\ School of Further and Continuing Education, University of Fort Hare, South Africa \\ Email: muzendaverity@yahoo.co.za \\ Ntombozuko Duku \\ School of General and Continuing Education, University of Fort Hare, South Africa
}

\section{Doi:10.5901/mjss.2014.v5n16p446}

\section{Abstract}

The delivery of the Clothing and Textiles in Zimbabwean universities has been marred by a lot of challenges and lecturer competency is one of the crippling factors. This study sought to establish how lecturer competency impact on the delivery of the Clothing and Textiles curriculum. The study employed a mixed method research paradigm. The sample comprised 60 respondents (32 lecturers, 2 Heads of Department, 24 students and 2 Operations managers). Questionnaires, interviews, focus group discussions, observations and document analysis were used as data collection instruments. Qualitative data was analysed through the use of themes and quantitative data was analysed using the SPSS software. Findings revealed that lecturers were finding difficulties in teaching the core courses in Clothing and Textiles due to incompetency. This study concedes that although lecturers have the suitable minimum requirements to teach in universities, that is Masters and PhD academic qualifications; it is the professional aspect on the delivery of Clothing and Textiles which is a source of the concern. The study recommended that in order to accurately inform early recognition, intervention and training programmes for lecturers who are not competent enough to deliver Clothing and Textiles, their areas of weakness should be identified first so as to enable university administrators to plan accordingly. The quality of the existing lecturing force must be improved mainly through extensive staff development training programmes, including those lecturers who trained long back to acquaint them with technical skills that are in line with the new technologies and global trends.

Keywords: Quality, delivery, Clothing and textiles, Curriculum, competency

\section{Introduction}

The quality of lecturing staff is a major determinant of the quality of graduates the universities produce and their eventual impact on the world of work and economic development (Nonaka, 2002). There is generally shortage of qualified lecturers in Zimbabwean universities. The few universities that offer Technical Vocational Education (TVE) lack qualified lecturers. Matoti (2010) asserts that the incompetence of lecturers as the chief implementers of curriculum can be a barrier to effective learning. The shortage has led to the use of unqualified lecturers which perpetuates the vicious circle of poor lecturers producing students who do not meet the standards required in the world of work. In Zimbabwean universities, many lecturers have left the teaching profession to escape the worsening economic situation with hyper-inflation having turned their salaries into pittances (Makochekanwa \& Kwaramba, 2010). This problem was also observed in some African universities (SARUA Handbook, 2009). Key to the success of a vocational programme is lecturers' competence and attitude. In support of this view, Rogan and Grayson (2003) stipulate that, lecturer capacity is a critical factor if quality results are to be realised in universities.

The Nziramasanga commission (1999) also found out that in universities, the lecturers were under qualified for their jobs. This is a big challenge to quality assurance in the delivery of TVE in universities, for qualifications fall at the heart of the link between economic demand and social demand, or between livelihood creators and livelihood seekers (Matoti, 2010). While the university curriculum is diversified to include vocational courses, frequently the teacher training curriculum has continued to emphasise on academic courses (Access Economics, 2010). This creates a knowledge gap between the lecturer and the curriculum in universities and ultimately, with the world of work. According to Stronge (2004) qualities of an effective lecturer entail his or her educational coursework, verbal ability, content knowledge, certification and teaching experience. For lecturers to be competent there is need for them to have good communication skills. Lecturers communicate with students through the use of verbal utterances as well as action. Competent lecturers know 
the type of students they are teaching, slow learners or fast learners. This enables them to pitch their pedagogy and methodology to the level which will enable students to understand what is being taught since if the lecturer uses the same methodology to all the students in a learning situation, it may not be as effective on one student as it can be to another student for students have different learning styles (Rani \& Shukla, 2012). Rani and Shukla, (2012: 33) affirm that:

Every student has his or her own learning style, for instance, some students enjoy listening to lectures, other prefer to read in library some like to be given specific assignment, others to define a problem for themselves and search for solutions, some prefer verbal interaction other like laboratory or other learning experience requiring manipulation .

It has been observed that when there is a discrepancy in the learning styles, students may become disoriented, restless and perform poorly. Therefore, a competent lecturer has to be skilled in choosing the suitable teaching methods for the subject he or she teaches.

Abott (2009) comments that competent lecturers have one distinct quality in the manner in which they plan their work, design and implement instruction and the way they assess students' work. What makes teaching and learning exciting is the fact that students have different learning styles which calls on the lecturer to be in a position to make use of different methodologies so as to meet the individual needs of the students for a method which makes learning to one student may not necessarily make learning come to another student (Higher Education Bureau, 2010). There is need for the lecturer to be well prepared so that he or she is able to control the class. This is also applicable to Clothing and Textiles (CT) in which instead of students designing and making patterns manually, the lecturer can expose students to the use of computer software that enables them to design and make patterns using the computer.

Stronge (2004), states that it is impossible for a lecturer to teach what he or she is not familiar with. According to Nel (1992), teacher training programmes must be designed in such a way that after the training, the teacher will be equipped with adequate knowledge which will enable him or her to deal with students with diverse needs. According to Wenglinsky (2000), lecturers who have specialised in a specific subject area are likely to produce good results in their subject areas. This is also the case with CT. A study in California avowed that lecturers who have specialised in Mathematics had their students attaining high marks in their achievement tests, (Fetler, 1999). Competency entails knowing the type of pedagogy one has to use as a lecturer in a learning situation and this enables one to determine the fundamental concepts and skills needed for the mastery of the subject (Langer, 2001). This, however, helps lecturers to link the content to the real life situations which enhances better understanding of the content. According to Wenglinsky (2002), lecturers with a better content knowledge enjoy the subject they teach which makes it easy for them to deliver the curriculum in a manner which makes it easier for students to understand.

Stronge (2004) strongly feels that without adequate educational coursework preparation, lecturers cannot exert themselves fully in their work. According to Stronge (2004: 11), educational coursework entails "courses teachers took as part of their preparation programme for teaching or as part of post graduate work to earn their certification." DarlingHammond (2000:98) in agreement affirms that:

\footnotetext{
Despite longstanding criticisms of teacher education, the weight of substantial evidence indicates that teachers who have had more preparation for teaching are more confident and successful with students than those who have had little or none.
}

Teacher certification varies from country to country. In most countries, proper lecturer certification entail that one is a highly competent lecturer. However, some renowned lecturers revel that if a lecturer is certificated, it does not follow that he or she is competent enough to deliver (Goldhaber \& Brewer, 2007; Laczko-Kerr \& Berliner, 2002). These authors claim that certification does not make a difference, but it is just one part that completes the puzzle of lecturer quality. Wayne and Youngs (2003) are of the opinion that for certification to be more acceptable, lecturers should be made to teach in their areas of specialisation. This applies more to CT where the lecturers need to show the ability to demonstrate knowledge in hands on skills. In a study of 359 learning institutions, carried out by Ross, Cousins, Gadalla and Hannay (1999), it was discovered that lecturers had decreased competency level when they were made to teach in an area they did not specialise in. This finding illustrates the impact on educators when they are assigned to an area they did not train in. In concurrence, Darling-Hammond (2001) claim that lectures who teach in their areas of specialisation produce better results than those assigned to areas they did not specialise in. This means that for lecturers to cater for students' individual differences and abilities and to impart skills to students, they should be well trained and well versed with their subject areas. Wong (2009) asserts that for students to achieve academically, there is need to change the way an institution is organised, but there is need to change the way lecturers teach. The same author further alludes that institutions that have good pass rates are those that have lecturers know the best instructional practice to employ in a 
learning environment and thus they will use them to achieve intended goals that is students' academic achievement. Ornstein and Hunkins (2004) argue that lecturers need to continually develop themselves within the education system to acquire different knowledge and teaching skills so as to face the new challenges, purpose and scope of the new CT curriculum. However, Grollmann (2008) postulates that promoting the quality of vocational lecturers rests on high level of education and preparation of individual lecturers. This needs to be complemented by policies which acknowledge some of the specific challenges in this field, such as the very specific nature of vocational knowledge and the need for cooperation between different profiles of vocational lecturers and the surrounding community in the world of work.

Another issue pertaining lecturer competence is the issue of their experience in the teaching field. There is no firm agreement on how many years makes a lecturer experienced (Stronge, 2004). This depends on the policies of the ministry in charge. Earl (2010) states that a lecturer's years of experience in the teaching field have an impact on how one delivers learning programme. Earl (2010) further alludes that lecturers who are just entering institutions face challenges in the delivery of learning programmes because they lack confidence. Darling-Hamond (2000) states that experience enables lecturers in colleges and universities improve throughout their careers. As a result, education must not end after one gets the certificate and signing a contract with the ministry. There is need for lecturers to continuously develop themselves by attending refresher courses and workshops. As a result, there is a mandate put in place by the Zimbabwe Council of Higher Education (ZIMCHE) to drive the change process, by helping identify and shaping the new competencies lecturers need. ZIMCHE has given all universities a mandate that by 2015 all lecturers in Zimbabwean universities should have registered for a Doctoral degree with an accredited university. This is against the backdrop that lecturers in universities were lagging behind in as far as upgrading themselves is concerned which adversely affect their delivery of the curriculum. Lecturers involved in the delivery of the CT curriculum in TVE should be given the opportunity to update their technical information, knowledge and skills through special professional development courses, practical training periods in enterprises and any other organised form of activity involving contact with the world of work (UNESCO, 2008). European Union, (2010) observes focusing on high quality teaching as key pre-requisite for high quality education and training in Institutions of Higher Learning.

Makochekanwa and Kwaramba, 2011 reiterate that lecturers should have the capability to interpret the national curriculum. Failure to do so results in poor lecture delivery for if the lecturer does not understand the syllabus; it is an obvious case that lecture delivery will be a nightmare. In essence, lecturers should be individuals of high calibre, who are able to deliver content and make learning come for students. Without well qualified and committed lecturers, learning becomes difficult because students of diverse abilities need different levels of attention. The researcher thus deems it necessary for the lecturers to be staff developed on syllabus interpretation, so that they may have confidence before the students when delivering a lecture. Although Centralised models of curriculum development have been put in place in universities, these have often neglected the most important variable in successful curriculum change that is the lecturer. For example, in Zimbabwe where ambitious departures in curriculum policy have been declared, there has been little evidence of the required training or repositioning which would translate these objectives into practice (Kanyongo, 2005; Mungazi 1985).

Due to lack of knowledge of the part of the lecturer, lecturer -pupil interaction is non-existent. This is as a result of fear of being asked questions they would not be able to answer due to lack of subject content as well as lack of confidence in themselves.

According to Earp (2010) lecturers should view students as active participants who can also contribute meaningfully to the learning process than to view themselves as the fountain of knowledge. The same author further alludes that this scenario is commonly practiced in northwest Europe, Scandinavia, Australia and Korea, southern Europe, Brazil and Malaysia. In support, Evans (1993:143) acknowledges that "If there is lack of public confidence in lecturer's professional knowledge, there will be a parallel crisis of confidence in lecturers' professional execution of duties". In the same line of thought, Wentzel (2002) postulate that lecturers' personal qualities and intelligence influence the way they handle lectures, and teaching aids (resource materials). Thus, the lecturer's level of professional competence can adversely influence effective curriculum delivery.

There is a general agreement that that teaching methods that involve students actively result in students performing well in their academic work and this makes it possible for all students to be part of the learning activities thus no one will feel to be an outcast (Crosling, Heagney \& Thomas, 2009; Parker etal., 2005; Thomas, 2002; Bamber \& Tett, 2001). Active learning is often associated with experiential, problem-based and project-based learning, and other forms of collaborative learning, endless reliance on the large lecture format. A lecturer exuding high levels of competency must have high expectations for the students he or she teaches (Higher Education Bureau). It is of paramount importance for a lecturer to be impartial when treating his or her students. A consistent lecturer treats students fairly and in the same way in any learning situation. Students are quick to pick on an unfair practice by the lecturer. For example, students complain 
of unfairness when lecturers treat one group of students differently or when they give preferential treatment to other students (Higher Education Bureau). If a lecturer expects less effort from students he or she is teaching, he or she will receive less effort in turn. As an effective lecturer one should portray an attitude that impresses on the students that he or she knows they can perform up to the level of the lecturer's expectations. This also gives students a sense of confidence. In CT a lecturer should ascertain students that they can produce artifacts which are up to the level of workmanship he or she expects. However, caution should be taken not to create unrealistic expectations for expectations for these will be the enabling factors to students' academic achievement.

\section{Research Methodology}

\subsection{Research Paradigm}

The post-positivism paradigm is a knowledge claim that challenges the absolute reliance on one knowledge claim as advocated by interpretivists and positivists (Maree, 2007; Creswell, 2003). The Post-positivism approach was relevant to this study since the researcher was interested in using different data collection instruments gathering evidence that could be used to examine the competencies of lecturers in the delivery of CT in universities.

\subsection{Research Design}

In this study, the Concurrent triangulation design was used which involves collecting both quantitative and qualitative data at the same time during the study (Cresswell, 2003). According to Kelly (2006) triangulation involves the use of different types of instruments in a single research study. This enhanced the researcher's understanding of the competency of lecturers for she would be looking at the phenomena from various angles.

\subsection{Population}

According to Walliman (2006) a population defines the total quantity of cases which are subject to one's study. Zimbabwe has a total of twelve universities, 8 of which are public universities and 4 private universities respectively. This study targeted all the 4 public universities that offer CT at degree level. There are 4 Clothing and Textiles industries which are fully operational in Harare. , so the researcher targeted 2 industries.

\subsection{Sample and Sampling Procedures}

From the above population, a sample was selected since it was not possible to carry out the study in all the universities and industries. Two universities and 2 Clothing and Textiles industries were selected in the study. The sample comprised 32 lecturers, 2 Head of Departments, 24 students and 2 Operations managers from the Clothing manufacturing industries. The sample was made up of 60 respondents. To come up with this sample, purposive sampling was used.

\subsection{Data Collection Methods}

Questionnaires, interviews, focus group discussions, document analysis, observations were used to collect data.

\subsection{Research Instruments}

Interviews aim at collecting rich descriptive data that help the researcher to understand the participant's construction of knowledge and social reality. In this study, 2 Heads of Department from both universities were treated to face-to-face interviews, 16 lecturers and 2 Operations managers from the Clothing Industries. Probing allowed the researcher to solicit for more information from the respondents as well as getting clarifications on some aspects pertaining to the delivery of the CT curriculum in universities.

Focus groups were also employed in this study. Twenty for students made up the 4 focus groups. According to Patton (2002) the use of focus groups enables the researcher to obtain meaning from the students' point of view in an open way. A focus group interview was based on the assumption that group interaction would be productive in widening the range of responses, activating forgotten details of experience and realising inhibitions that may otherwise discourage participants from disclosing information on the delivery of the CT curriculum (Maree, 2007). 
Self- administered questionnaires were also used in this study. This was an advantage for it ensured a $100 \%$ response rate. To some extent, this overcame the problem that usually arises with the use of questionnaires, which is that a large number of respondents might not return the questionnaires (Maree, 2007). In this study, questionnaires had the advantage of soliciting different views from respondents and allowed for anonymity and privacy so that the researcher would get more truthful responses from lecturers on sensitive issues on the competency of CT lecturers in Zimbabwean universities (Babbie, 2008).

Documents were also analysed in this study. Such documents included schemes and plans of work, students log books, university policy documents, files from industries, policy circulars, minutes of meetings and letters. When one uses documents as a data gathering technique, one will focus on all types of written communications that may shed light on the phenomenon that one is investigating (Maree, 2007). Borg, Gall, and Gall (2003) posit that qualitative researchers often study written communication found in natural settings as data sources.

Observations enabled the researcher to understand the framework of the programmes. According to Cohen, Manion and Morrison (2007) observations enable the researcher to discover phenomena that participants might not freely talk about, for instance in interview situations. In this study, it enabled the researcher to collect data on the physical setting organisation of the universities' laboratories or workrooms, as well as well as the work rooms in the Clothing manufacturing industries.

\subsection{Data Analysis}

Data analysis is a process which involves the application of techniques to describe and illustrate, condense and evaluate data (Shamoo and Resnik, 2003). In this study both quantitative and qualitative data were interpreted together and analysed concurrently.

\subsection{Measures to ensure Validity/ Reliability and Trustworthiness}

Validity in quantitative data is a critical issue and might be improved through careful sampling, appropriate instrumentation and appropriate statistical treatment of the data. In this study, the researcher ensured that the instruments were designed in such a way that they measured what they were supposed to measure, that is the competency of lecturers in the delivery of the CT curriculum. This means that the data must accurately describe what it is targeted to describe. Guba and Lincoln (1985) argue that a qualitative study cannot be called transferable unless it is credible. Verbatim statements were used to enhance accuracy and trustworthiness.

\subsection{Ethical consideration}

In this study, the researcher made sure that the names of the universities and industries remained anonymous. Participation in the study was voluntary. Information about the participants was kept private from the public so as to ensure the participants' right to confidentially.

\section{Results and Discussions}

In response to the question on whether or not lecturers specialised in $\mathrm{CT}$, it emerged from the interviews with lecturers that all the lectures had specialised in $\mathrm{CT}$. However, data gathered from questionnaires with lecturers revealed that not all of them had specialised in Clothing and Textiles. All lecturers in university A 16(100\%) had specialised in CT. From university B, 5(31.25\%) had specialised in CT and 3(18.75\%) of the lecturers highlighted that they had specialised in Art and Design. After further probing on why they were teaching CT yet they did not specialise in it, the lecturers stated that they were teaching other courses with Clothing and Textiles components which were different from their specialisation as revealed by lecturers in interviews. For instance lecturers were offering just a module or course in $\mathrm{CT}$, for instance fabric dyeing, fabric printing but as time went on they were given more courses in CT due to staff shortages. They accepted the offer due to fear of losing their jobs. Thus it can be observed that in some universities, although lecturers had specialised in other subjects, they were teaching CT. A fact that cannot be denied is that these lecturers could lack both content and pedagogic skills since they were not necessarily tailored to teach CT.

In this study, it was indispensable to establish whether or not lecturers were adequately trained to deliver CT for lecturers are the channel through which information passes to the students in the learning situation in universities. According to Narvaez (2006), lecturers' main task is to plan what is to be learnt by students, that is the curriculum. This is 
done by drawing from the goals of education and then lecturers get to execute them in a professional manner. Data from the interviews with the lecturers unearthed the fact that they were adequately trained to deliver CT. The reason provided by lecturers as deduced from their explanations was that they were producing good results or high pass rates in CT. For example respondent UAL said:

all the years we have had high pass rates in Clothing and Textiles.

In support of this claim respondent HOD-B explained:

Yes, I have a Masters degree which is higher than the degree the university is offering. (HOD-B)

There were mixed feelings here for some respondents alluded to the fact that they felt they were not adequately trained to deliver CT since the content they have was now out-dated because of so many years in the teaching field. Respondent UAL remarked:

Our content is out-dated since we trained more than 13 years ago. Trends in Clothing and Textiles have changed so many times because of the new technologies so we need staff development.

Respondent HOD-A concurred with the view that the content or information they have from colleges and universities is out-dated, commenting: I feel not adequately trained since there are so many changes that have taken place as a result, I need more training to
keep at par with the changes in the Clothing and textiles arena.

One of them stated that:

When I started, I was teaching Art and Design as a module in Clothing and Textiles, but due to manpower shortages in the department I was completely absorbed in teaching all the modules. I could not deny for fear of losing my job.

There was also evidence to the fact that besides being qualified, lecturers lacked some experience to handle practical skills in CT for most lectures were done theoretically. It was also evident that lecturers did not know how to go about the practical part because of lack of enough training in colleges and universities. It is of concern that when some aspects of the curriculum are done in a different manner from the way they are planned, it is the responsibility of the Heads of Departments and lecturers to ensure the programmes do not depart from the set objectives of the curriculum. Schweizer and Kelly (2005) espoused that competent lecturers are masters of their subject matter, exhibiting great expertise in the subjects they teach. They are able to present material in an enthusiastic manner and instil a desire in their students to learn more. For example, it is not expected for curriculum to feature theory only and not cover practical work, if the latter was part of the planned work. If that happens, it becomes a serious disparity that will stand as a new curriculum altogether. Practical lectures are a major element of the CT curriculum and if they are not taught in lectures, this represents a major deviation from the planned route. This implies that curriculum delivery is enormously determined by lecturers' ability to make it happen with expertise.

It was also thought that university lecturers had areas of strength in CT. Thus, these areas of strength were considered important in further illuminating the problem under investigation. In order to bring out what was going on in curriculum delivery, respondents were asked to detail their areas of strength in the CT curriculum. Qualitative and quantitative data gave indications that most lecturers' areas of strength were Wardrobe planning, Grooming, Experimental design in clothing, Cultural context of clothing and the society, fabric construction and product development. Through triangulation, the study established that lecturers had difficulties in delivering some areas or courses in CT.

From the overwhelming evidence of the greatest percentage 16(100\%) in these courses, Organic chemistry, Textile science and Technology, Garment construction, Pattern making and fabric printing and dyeing, the study established that this would be a crippling factor in the delivery of the CT curriculum in universities since all the lecturers who participated in the study unearthed that were finding difficulties in these courses.

This study established that universities had academically qualified lecturers who were lacking professional qualifications. The lecturers and the Heads of Departments had the minimum required qualifications. Although these had strengths in areas like Wardrobe planning, Grooming, Experimental design in clothing, Cultural context of clothing and the society, fabric construction and product development, they were not fully professionally qualified in the area. This is evidenced by the courses they highlighted as posing some challenges in their teaching which are very fundamental if one 
is to excel in CT.

Views of lecturers were sought on the issue of what challenges they were encountering in the delivery of CT in universities. Of great interest is that the findings of the study from both qualitative and quantitative data unearthed that capacity to teach, machinery and resources and relationship with industries were considered a serious concern by lecturers and Heads of Departments and were thus the most contested issues of all the challenges in the delivery of CT. These were followed by the attitude of students, inadequate time for lectures and attitude of management. The findings unveiled that from both university A and B, $22(65 \%)$ lecturers exposed that lecturers are not well capacitated to deliver CT and 22 (65\%) sited shortages of machinery/ equipment as one of their challenges. Ten (29\%) lecturers felt their challenge lay mostly on the university's relationship with the industry. Six (18\%) lecturers sited students' attitudes. Inadequate time for lectures and Attitude of management each had a frequency of $1(3 \%)$ lecturers. Data captured from questionnaires also portrayed the same picture. The majority of the lecturers from university A, $8(100 \%)$ sited machinery as a challenge and $6(18 \%)$ sited capacity and relationship with industries respectively. From university B, $8(100 \%)$ revealed that the greatest challenge lecturers faced in the delivery of CT was incompetence, followed by $8(100 \%)$ who sited machinery and resources. Six (18\%) sited relationship with industry whilst $1(3 \%)$ sited inadequate time for lectures and attitude of management respectively. Assessment did not seem to be posing a challenge to lecturers.

As a follow up on challenges lecturers were encountering in the delivery of $\mathrm{CT}$, the lecturers responded to what the universities have done to respond to these challenges through interviews and the questionnaire. It emerged from their responses that the universities were purchasing machinery at a very slow pace and in lesser numbers. Nothing has been done regarding staff development and the relationship between universities and industries. In response, lecturers had this to say:

Universities are trying to purchase machinery and other resources but at a very slow pace. Nothing has been done on staff development. Currently not much has been done. Support in provision of some machinery and its maintenance is given but it is not adequate. (UAL)

Equipment is very expensive such that universities cannot afford. Most of this machinery are manufactured abroad, as a result, the university has to liaise with some industries with this machinery, but students just see the machinery. They don't have the chance for hands- on. (UBL)

It emerged from the study that although universities were willing to purchase the machinery and equipment, lack of enough funds remains a major deterring factor. Purchasing of machinery and equipment is being hampered by the high cost of machinery on the market and the fact that some machinery has to be imported from overseas countries. The researcher reasons that adequate machinery and equipment is a prerequisite for effective delivery of the CT curriculum, hence lack of adequate machinery incapacitates them. Furthermore, poor resources and conditions hinder lecturers from performing to their best levels. The aims of the curriculum in vocational education is on enabling students to become operational by acquiring relevant skills which will make it possible for them to make a smooth transition from universities into the industries (Tribe, 2005; Tribe, 2002).

Data were also elicited from respondents intended to find out teaching methods which lecturers use in the delivery of CT lectures. From students' interview data, it emerged that research and presentations and group work were dominant methods used by lecturers during programme delivery in University A. This data correlates with what the two focus groups from university B stated in their responses. However, through triangulation of data, results from document analysis revealed that when scheming and planning what to teach, lecturers list different teaching methods, like whole class demonstrations, group demonstrations, spot demonstrations, question and answer, but when it comes to the actual lecture delivery, they did not use these methods. Thus findings of the study revealed that there were vast differences between the methods lecturers planned to use in lectures from the ones they actually used in lectures. Research suggests that improving student's performance can be implemented by changing teaching methods. The lecturer must be willing to change in order to initiate an effective program (Schneider, Gruman, \& Coutts, 2012). Students had this to say:

They use group work, research and presentations. We are given a topic to research on in groups and one of us presents on behalf of the group. Individual work- the lecturer gives us a task and we work individually. (FGA1)

Research and presentations, where we are given a topic to research on individually, or in pairs or groups and one presents it to the whole class. Discussions-the lecturer gives the class a topic and we discuss as a class. (FGB2)

Still on teaching methods, students responded to whether there were any other teaching methods they would prefer their lecturers to use. Students commented: 


\begin{abstract}
Spot demonstrations -As we are doing practical lectures, lecturers should do spot demonstrations, because we learn more when a lecturer spot demonstrates a process to us in groups rather than just explaining. (FGDA1)

Field trips- We visit textile companies and see how they do their work. We learn better by seeing the actual processes being done, e.g weaving than for the lecturer to explain it in class. One has to write a report on every company visited on how they do their work, management structure. (FGDB2)
\end{abstract}

From students' revelations, it emerged that students were yearning for teaching methods that allowed the lecturer to interact with them so that learning became alive when students understood better. On the same aspect, it was also revealed that students preferred teaching methods which allowed them to marry the theory they got in class with practice in the industries as they advocated for field trips.

\title{
4. Conclusions
}

It was established that the delivery of $\mathrm{CT}$ in universities has been marred by an array of problems. Lecturers were finding difficulties in teaching the core courses in $\mathrm{CT}$ due to incompetency. This has been aggravated by the fact that the training the lecturers received in Teachers' Colleges no longer matches with the pedagogy they have to deliver to CT students. This acts in detriment to the students who are at the receiving end for they are not equipped with the necessary hands on skills when they leave the universities. Findings affirm that the dearth of equipment and machinery, dampened morale and negative perceptions further intensifies this challenge. However, this study concedes that although lecturers have the suitable minimum requirements to teach in universities, that is Masters and $\mathrm{PhD}$ academic qualifications; it is the professional aspect on the delivery of CT which is a source of the concern.

\section{Recommendations}

In order to accurately inform early recognition, intervention and training programmes for lecturers who are not competent enough to deliver CT, their areas of weakness should be identified first so as to enable university administrators to plan accordingly, having these areas in mind.

The quality of the existing lecturing force must be improved mainly through extensive staff development training programmes, including those lecturers who trained long back to acquaint them with technical skills that are in line with the new technologies and global trends. University lecturers should upgrade their knowledge and skills so as to keep abreast with the dynamic fashion, clothing trends and technology so that when students come on attachment, the industrial personnel will just refine the skills not to start from scratch, teaching the students basics they should have done at university level. This will enable them to produce students with the required competence.

There is need to increase support (both material and financial) towards staff development programmes that focus on lecturer competence since they are an important approach that can upsurge lecturer competence. However, such programmes should be differentiated according to the level of education of the lecturers in order to cater for variances in pedagogy and methodological requirements.

\section{References}

Abbott, M. (2009). Conversations about teaching. Marylhurst University.

Access Economics (2010)

Babbie, E. A. (2008). The basics of social research, Thomson Learning. Inc. USA.

Bamber, J and Tett, L (2001) Ensuring integrative learning experiences for non-traditional students in Higher education. Journal of Widening Participationand Lifelong Learning, 3.1, p8-18.

Borg, W.R., Gall, G. and Gall, J. P. (2003).Educational research: An introduction. New York: Longman.

Cohen, L,. Manion, L., and Morrison, K., (2007). Research methods in education. Padstow: Cornwal.

Creswell, J. W. (2003). Research design; Quantitative, and mixed methods approaches. London: Sage.

Crosling, G., Heagney, M., \& Thomas, L. (2009). Improving student retention in higher education: Improving Teaching and Learning. Australian Universities' Review, 51(2).

Darling-Hammond, L. (2000). Teacher quality and student achievement: A review of state policy evidence.

Darling-Hammond, L. (2001). The challenge of staffing our schools. Educational Leadership, 58(8), 12-17.

Earl, L. \& Katz, S., (2010). Learning about networked learning communities. School Effectiveness and School Improvement, 21(1), 2751.

Earp, B. D. (2010). Automaticity in the classroom: Unconscious mental processes and the racial achievement gap. Journal of Multiculturalism in Education, Vol 6 No 1, 1-22. 
Evans, R. N. (1993). Career Education and Vocational Education: Similarities and contrast. Boston: Fieldman.

Fetler, M. (1999). High school staff characteristics and mathematics test results. EducationPolicy Analysis Archives, 7(9).Retrieved from http://epaa.asu.edu/ojs/article/view/544 on 19/03/2014

Goldhaber, D., \& Anthony, E. (2007). Can teacher quality be effectively assessed? National board certification as a signal of effective teaching. The Review of Economics and Statistics, 89(1), 134-150.

Grollmann, P. (2008). The Quality of Vocational Teachers: Teacher Education, Institutional Roles and Professional Reality. European Educational Research Journal, 7(4), 535-547.

Guba, E. G. \& Lincoln, Y. S., (1985). Establishing trustworthiness. Naturalistic inquiry, 289-331.

Gumbo, S.D. (2006) Vocationalising Curriculum in Zimbabwe: An Evaluation Perspective Paper presented at the vocationalising Education Conference, London.

Laczko-Kerr, I., \& Berliner, D. C. (2002). The effectiveness of "Teach for America" and other under-certified teachers on student academic achievement: A case of harmful public policy. Education Policy Analysis Archives, 10(37). Retrieved October 1, 2013, from http://epaa.asu.edu/epaa/v10n37/

Langer, J. A. (2001). Beating the odds: Teaching middle and high school students to read and write well. American Educational Research Journal, 38(4), 837-880.

Makochekanwa, A., \& Kwaramba, M. (2010). Dwindling access to basic services in Zimbabwe.

Maree, K, (2007) First Steps In Research. Van Schaik Publishers, Pretoria, South Africa.

Matoti, S. N. (2010). The unheard voices of educators: perceptions of educators about the state of education in South Africa. South African Journal of Higher Education, 24(4), 568-584.

Narvaez, D. (2006). Integrative ethical education. Handbook of moral development, 703-733.

Nel, J. (1992). Preservice teacher resistance to diversity: Need to reconsider instructional methodologies. Journal of Instructional Psychology, 19, 23-27.

Nonaka, I., Toyama R. \& Konno N. (2002) SECl, Ba and Leadership: a unified model of dynamic knowledge creation, in: S. Little, P. Quintas \& T. Ray (Eds) Managing Knowledge (London, Sage).

Nziramasanga, C. T. (1999). Zimbabwe Report of the Presidential Commission of Inquiry into Education and Training. (August 1999).

Ornstein. C.A. \& Hunkins, P.F (2004). Curriculum: Foundations, principles and issues. (4th Ed) Boston: Pearson Education Inc.

Parker, S, Naylor, P \& Warmington, P (2005), 'Widening participation in higher

Patton, M. Q. (2002). Qualitative evaluation and research methods (3rd Ed.). Newbury Park, CA: Sage.

Rani, P \& Shukla, S.C (2012) Learning Styles in Education. Volume 2. Issue 5.

Rogan, J. M., \& Grayson, D. J. (2003). Towards a theory of curriculum implementation with particular reference to science education in developing countries. International Journal of Science Education, 25(10), 1171-1204.

Ross, J. A., Cousins, J. B., Gadalla, T., \& Hannay, L. (1999). Administrative assignment of teachers in restructuring secondary schools: The effect of out-of-field course responsibility on teacher efficacy. Educational Administration Quarterly, 35(5), 782-805.

SARUA Handbook, (2009): A guide to the public universities of southern Africa. Southern African Regional Universities Association.

Schneider, F. W., Coutts, L. M., \& Gruman, J. A. (2012). Applied social psychology: Understanding and addressing social and practical problems. (2nd ed.). Thousand Oaks, CA: Sage Publications, Inc.

Schweizer,D.M \& Kelly,G.J, (2005): Journal of Geoscience Education v53, n1 p.75-84.

Shamoo, A.E., Resnik, B.R. (2003). Responsible Conduct of Research. Oxford University Press.

Stronge, J. H., Tucker, P. D., \& Hindman, J. L. (2004). Handbook for qualities of effective teachers. ASCD.

Thomas, E, Woodrow, M \& Yorke, M. (2002) Access and Retention', in Layer, G etal. (eds) Student Success in Higher Education. Bradford: Action on Access.

Tribe, J. (2002). Education for ethical tourism action. Journal of Sustainable Tourism, 10(4), 309-324.

Tribe, J. (2005). New tourism research. Tourism Recreation Research, 30(2), 5-8.

UNESCO. (2008). Towards Information Literacy Indicators. Conceptual framework paper with a list of potential international indicators for information supply, access and supporting skills by UNESCO Institute for Statistics.

Walliman, N. (2006). Social Research Methods. London: Sage publications.

Wayne, A. J., \& Youngs, P. (2003). Teacher characteristics and student achievement gains: A review. Review of Educational Research, 73(1), 89-122.

Wenglinsky, H. (2000). How teaching matters: Bringing the classroom back into discussions of teacher quality. Princeton, NJ: Millikan Family Foundation and Educational Testing Service.

Wenglinsky, H. (2002). How schools matter: The link between teacher classroom practices and student academic performance. Educational Policy Analysis Archives, 10(12). Retrieved March, 20, 2014

Wentzel, K. R. (2002). Are effective teachers like good parents? Teaching styles and student adjustment in early adolescence. Child development, 73(1), 287-301.

Wong, H. "Teachers are the Greatest Assets." Teachers Net Gazette. May 2009. 